\title{
СПОСОБИ ЗНИЖЕННЯ ШКОДОЧИННОСТІ ЗБУДНИКІВ ВІРУСНИХ ХВОРОБ КАРТОПЛІ
}

\author{
Кучерявенко Оксана Олександрівна \\ науковий співробітник \\ Інститут сільськогосподарської мікробіології та агропромислового виробництва НААН України, \\ м. Чернігів, Україна \\ okskucher83@gmail.com \\ Киріг Олександр Вікторович \\ СТОВ «Дружба Нова», смт. Варва, Чернігівська обл., Україна \\ ORCID: 0000-0001-5127-6451 \\ altrockman1986@gmail.com \\ Тимошенко Олена Петрівна \\ кандидат сільськогосподарських наук, доцент \\ Національний університет «Чернігівська політехніка», \\ м. Чернігів, Україна \\ ORCID: 0000-0002-6888-7192 \\ timosh_alena@ukr.net \\ Дмитрук Оксана Олександрівна \\ науковий співробітник \\ Інститут сільськогосподарської мікробіології та агропромислового виробництва, \\ м. Чернігів, Україна \\ ORCID: 0000-0002-5839-9902 \\ oks.dmytruk@gmail.com \\ Бондар Ірина Миколаївна \\ старший викладач кафедри аграрних технологій \\ та лісового господарства \\ Національний університет «Чернігівська політехніка» НААН України, \\ м. Чернігів, Україна \\ ORCID: 0000-0002-8407-0748 \\ irynapozitiv@gmail.com
}

Наведено результати багаторічних даних моніторингових досліджень щодо поширення у розсадниках елітного насінництва картоплі вірусних хвороб, які викликають значні втрати урожаю та якості бульб. Встановлено, що найбільш поширеними є M-, S-, Y-віруси картоплі, як у моноінфекції, так і у складі патокомплексів. Описано класичні методи боротьби із вірусними хворобами картоплі: біотехнологічні, фітосанітарні, хімічні та агротехнічні. Проведено аналіз досліджень з питань застосування фізіологічно активних речовин, антивірусних продуктів метаболізму різних мікроорганізмів та інгібіторів вірусів із широким спектром антивірусної дії, які у цілому здатні стимулювати природні захисні механізми рослин і є перспективними у стратегії захисту рослин від вірусних інфрекцій.

Ключові слова: картопля, вірусна інфекція, біологічні антивірусні речовини, фізіологічно активні речовини, біопрепарати.

DOI https://doi.org/10.32845/agrobio.2021.2.4

Вступ. В Україні картопля посідає одне з перших місць серед інших сільськогосподарських культур за універсальністю використання у господарстві. Вона $є$ важливою продовольчою, кормовою й технічною культурою. Врожайність та якість картоплі здебільшого залежать від ступеня ії ураження фітопатогенами різної етіології.

Одним із найбільш шкодочинних захворювань картоплі $€$ вірусні інфекції, перебіг яких у рослинах супроводжується порушенням фізіологічних процесів, таких як зниження інтенсивності фоотосинтезу; порушення інтенсивності дихання; зниження активності синтезу нормальних клітинних компонентів та інш. і, як наслідок, зниження врожайності та якості продукції культури (Tesljuk et al., 2008). На відміну від інших інфекційних захворювань рослин, вірусні хвороби мають низку особливостей: в інфікованій рослині вірус зберігається протягом усього її життя, а також у її вегетативному (а інколи і генеративному) потомстві (Kuz'mich \& Balashova, 2011). Сьогодні виявлено більше двох десятків 
вірусів, які пошкоджують картоплю. Майже десять із них завдають значних збитків картоплярству через значне поширення і суттєве зниження врожайності бульб.

До найбільш поширених в Україні слід віднести: X-, Ү-, М-, S-віруси картоплі, ВСЛК. Через ураження найбільш поширеними вірусами X, S, M, Y, L втрати урожаю сягають від 5 до 80 \% (Kolomiec, 2005; Suchasnij stan agrocenozu kartopljanogo polja i shljahi reguljuvannja jogo chisel'nosti).

За багаторічними результатами досліджень лабораторії вірусології Інституту сільськогосподарської мікробіології та агропромислового виробництва НААН України (м. Чернігів) у розсадниках елітного насінництва картоплі виявляються M-, S-, Ү-віруси картоплі, як у моноінфекції, так і у складі патокомплексів. Превалює в посівах ентомофільний М - вірус картоплі в моноінфекції $(36,2$ \%) або у комплексі з іншими мозаїчними вірусами: МBK+SBK виявлений у рослинах 23,4 \%, МBK+SBK+YBK - 29,8\%, MBК+YBK - 6,4 \%, SBК+YBK - 2,1\%, SBK - 2,1\% обстежених сортів (рис. 1) (Bova et al., 2013; Monitoring virusnyh boleznej kartofelja na Poles'e Ukrainy, 2006; Kolomijec', 2007; Metody kontrolju fitovirusologichnogo stanu agrocenoziv z kartopleju ta zernobobovymy kul'turamy, 2015).

В більшості зразків виявлено різні варіанти комплексів трьох домінуючих вірусів мозаїчної групи МBK, SBK, ҮВК. Патокомплекси за участі МВК серед всіх проаналізованих випадків складають 95,8 \%, за ҮВК - 38,3 \%, за SBK - 57,4 \% (Monitoring virusnyh boleznej kartofelja na Poles'e Ukrainy, 2006; Kolomijec', 2007; Metody kontrolju fitovirusologichnogo stanu agrocenoziv z kartopleju ta zernobobovymy kul'turamy, 2015). Втрати врожаю картоплі від М - вірусу в залежності від сорту та умов навколишнього середовища досягають 25-50 \% (Kostiw, 2011) та більше при змішаній інфекції - 75 \% (Brunt, 2001).

Таким чином, при вирощуванні здорового вихідного матеріалу у польових умовах протягом 2-3 років спостерігається високий ступінь ураженості його вірусами мозаїчної групи. Відтак, істотним резервом збільшення врожаю картоплі та підвищення якості продукції, а також, що не менш важливо, якості насіннєвого матеріалу є захист рослин від вірусної інфекції. Поки що не існує надійних засобів боротьби із фітовірусними інфекціями, що пов'язано з особливостями біології збудників, тому захист картоплі від вірусних хвороб носить тимчасовий та профілактичний характер (Ambrosov et al., 1985).

Одним із важливих прийомів боротьби з вірусними хворобами картоплі $€$ отримання безвірусного матеріалу та прискорене його розмноження за використання біотехнологічних методів. Для біотехнологічного оздоровлення сортів картоплі використовують метод культури меристеми, який доповнено хіміотерапією та термотерапією, що значно підвищує ефективність оздоровлення. Розроблений технологічний процес, включає не лише оздоровлення, а й вивчення впливу елементів технології на збереження ідентичності сортових ознак, збільшення продуктивності матеріалу за рахунок фрізіологічного оновлення та відбору найбільш продуктивних клонових ліній, на розробку і застосування системи контролю вірусологічного стану регенерантів на всіх етапах технології одержання оздоровленого вихідного матеріалу.

Технологія вирощування оздоровленого насіннєвого матеріалу картоплі також передбачає застосування комплексу заходів, які обмежують розповсюдження фітопатогенних вірусів в агроценозах цієї культури. До числа основних заходів відносяться:

- фітосанітарні методи захисту від вірусів - просторова ізоляція насіннєвої картоплі від площ продовольчої картоплі; проведення регулярних фітопрочисток із видаленням хворих рослин; облік безкрилих попелиць та прогнозування строків їх розвитку;

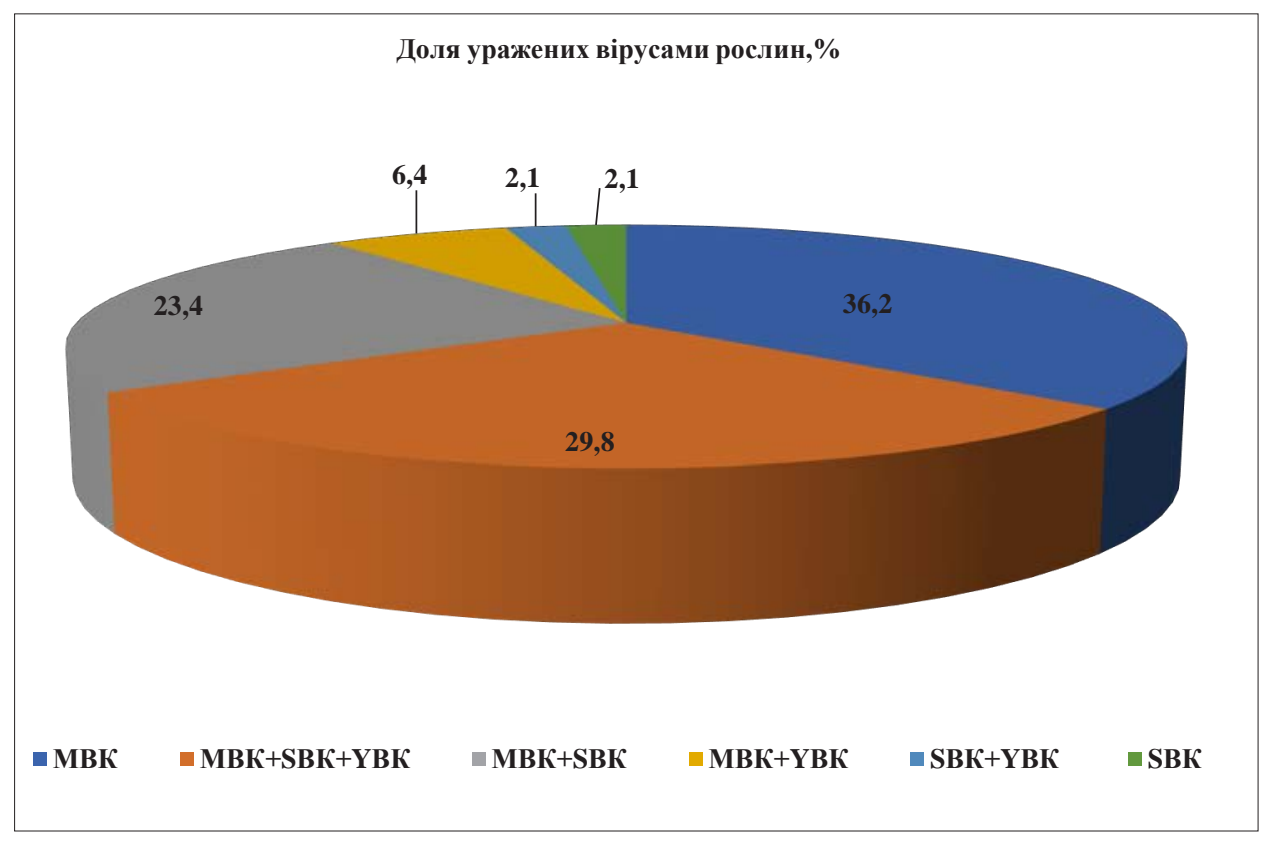

Рис. 1. Результати фітовірусологічного моніторингу насаджень насіннєвої картоплі, 2015 - 2020 рр. 
- хімічні методи захисту - обприскування рослин картоплі інсектицидами та препаратами мінеральних масел проти попелиць-переносників вірусної інфекції;

- агротехнічні методи захисту - ранні строки висаджування пророщеними бульбами до початку масового льоту попелиць; густота садіння бульб у розсаднику добору клонів має бути 50-70×70 см, що виключає контакт рослин між собою та знижує розповсюдження вірусів контактним шляхом;

- створення умов для швидкого росту і розвитку рослин картоплі в початковий період вегетації (Vlasov \& Larina, 1982; Shelud'ko, 1970; Soroka, 2005; Gnutova \& Zolotarev, 2011).

Сьогодні актуальним $є$ пошук ефрективних, екологічно безпечних прийомів зниження шкодочинності вірусних хвороб, починаючи з перших етапів насінництва. У пошуку оптимальних варіантів покращення фітосанітарного стану насаджень картоплі все більше використовують регулятори росту рослин, які позитивно впливають на урожайність і якість продукції та істотно підвищують стійкість рослин до несприятливих фракторів середовища - коливання температури, нестачі вологи, фрітотоксичної дії пестицидів, ураження хворобами та шкідниками (Shevchuk \& Doroshenko, 2000).

Застосування фізіологічно активних речовин, здатних стимулювати природні захисні механізми рослин, розцінюють як перспективну стратегію захисту рослин від вірусних інсекцій (Harina et al., 2007).

Існує багато відомостей про антивірусні властивості продуктів метаболізму різних мікроорганізмів, антибіотиків та інших речовин. Відомі також спроби оздоровлення рослин від вірусів за допомогою інгібіторів, які продукуються деякими дріжджами та грибами. Ці досліди не завжди давали позитивні результати, проте вони свідчать про наявність мікроорганізмів і рослин, здатних утворювати інгібітори з широким спектром антивірусної дії проти фрітопатогенних вірусів (Bawden, 1954; Mjet'juz, 1973; Gray, 1955; Bobyr', 1966; Krylov \& Usol'ceva, 1976).

А. Д. Бобирь у своїх дослідах випробовував культури різноманітних дріжджів, грибів роду Penicillium, бактерій роду Pseudomonas, антибіотики та інші речовини на антивірусну дію проти вірусів пасльонових. Він встановив, що фільтрати культуральних рідин 15 різних рас та видів дріжджів, трьох культур бактерій роду Pseudomonas, трьох культур грибів роду Penicillium, антибіотики іманін, аренарин і граміцидин при профілактичному застосуванні на тютюні, томатах, перці, баклажанах та картоплі значно пригнічували накопичення X-, Y-, S-, М-вірусів картоплі, вірусу тютюнової мозаїки та бронзовості томатів (Bobyr', 1974).

М.В.Пріданніков досліджуючи природні регулятори процесів, пов'язаних з вилупленням личинок цистоутворюючих нематод виявив у водних екстрактах гомогенату яєць Globodera rostochiensis речовини здатні індукувати стійкість рослин тютюну до ВТМ (Pridannikov, 2007). На думку автора, антивірусна активність цих речовин може бути важливим для подальшого їх вивчення з метою розробки віруліцидів.

3 літературних джерел також відомо про здатність бактерій Pseudomonas fluorescens індукувати стійкість рослин тютюну до вірусу некрозу тютюну, томатів - до вірусу плямистого в'янення томатів, Bacillus pumilis та Serattia marcescens зумовлють пригнічення розвитку вірусу мозаїки огірка в рослинах Arabidopsis thaliana, деякі ризобактерії впливають на розвиток інфекції, спричиненої вірусом зеленої крапчастої мозаїки огірка (Harina et al., 2007; Loon et al., 1998; Maurhofer et al., 1998; Kandan et al., 2005; Ryu et al., 2004).

Сьогодні досліджено ефективність речовин біологічного походження (у тому числі тих, які $€$ основою біопрепаратів), які стимулюють ріст і розвиток рослин та одночасно підвищують їх стійкість до вірусних захворювань (Taran et al., 2004; Ponomarenko \& lutyns'ka, 1999; Sheveluha \& Blinovskij, 1990).

Л.К. Жеребчук разом із співавторами (Zherebchuk et al, 1974) у своїх дослідженнях вивчали вплив гібереліну на активність РНК-ази та репродукцію Х-вірусу картоплі. Вони встановили, що активність ферменту підвищується як при механічному пошкодженні листків картоплі, так і за інфікування рослин ХВК. У випадку обробки рослин гібереліном, нанесення якого на рослини відбувалося без будь-якого механічного пошкодження тканин, спостерігали активацію фрерменту рибонуклеази у листках рослин, а також його синтезу. Було зроблено припущення, що підвищення нуклеаз у клітині, індуковане гібереліном, в якійсь мірі впливає на деполімеризацію нуклеїнових кислот вірусу в момент її вивільнення з білкової оболонки, внаслідок чого концентрація вірусу в листках картоплі, оброблених гібереліном до їх зараження, була незначною.

Схожі результати були отримані Т.І. Мусорком разом із колегами при вивченні впливу кінетину - біологічно активної речовини групи цитокінінів на активність РНКази та репродукцію ВТМ у листках тютюну (Musorok et al., 1976). Встановлено, що обробка інокульованих ВТМ листків тютюну розчином кінетину у низьких концентраціях (2-4 мг/л) знижувала активність ферменту та збільшувала інфекційність соку уражених листків до 250 \%. При більш високій концентрації кінетину (10-30 мг/л) відбувалось менш стрімке зниження РНК-ази, а інфекційність соку знижувалась на 72-87 \% відносно контролю (інфіковані ВТМ листки тютюну без обробки кінетином).

Л.Н. Трофимець із співавторами (Pat. 2072779 Rossija) дослідили противірусні властивості арахідонової кислоти (АК) та захистили патентом спосіб її застосування як індуктора стійкості пасльонових до збудників вірусних захворювань. За результатами імуноферментного аналізу обробка рослин тютюну, уражених ВТМ, водним розчином АК у концентрації $10^{-7} \mathrm{M}$ сприяла зниженню концентрації вірусу у 8,6 разів. Результати досліджень з картоплею показують, що передсадивна обробка бульб та вегетуючих рослин картоплі арахідоновою кислотою значно знижує відсоток ураженості вірусами. При цьому урожайність збільшується на 67 \% відносно контролю (обробка бульб та рослин водою).

Низкою наукових досліджень показано, що речовинами, які мають здатність стимулювати стійкість рослин

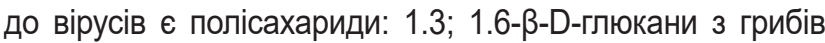
(Rouhier et al., 1995), та бурих водоростей (Reunov et al., 2000), 1.3; 1.4-ß-D-глюкан з лишайника Cetraria islandica 
(Stubler \& Buchenauer, 1996), хітозан (Chirkov, 2002), фукоідан (Lapshina et al., 2006), олігосахариди, отриманий з галактоглюкоманана (Slovakova et al., 2000), к/ $/$-каррагінан з червоних водоростей (Barabanova et al., 2006).

Співробітниками Тихоокеанського інституту хімії ДВО РАН проведено електронно-мікроскопічне вивчення впливу фукоідану з бурої водорості Fucus evanescens на накопичення X-вірусу картоплі у клітинах мезофілу Datura stramonium $L$. та хітозану з панцеру краба на накопичення і стан часток ВTM в клітинах мезофілу Nicotiana tabacum L. Показано, що обробка листків дурману фукоіданом (1 мг/мл) за добу до зараження ХВК сприяло меншому накопиченню вірусних часток, ніж у необробленому контролі. За допомогою ультраструктурно-морфометричного аналізу встановлено, що під дією фукоідану підвищується білок-синтезуюча здатність клітин (збільшуються розміри ядерець, підвищується кількість мітохондрій і мембран гранулярного ендоплазматичного ретикулуму). Разом з цим при обробці фукоіданом спостерігається деяка активізація літичного компартмента, яка призводить до деструкції вірусних часток i, таким чином, може розглядатися як один з обумовлених полісахаридом захисних механізмів клітин, обмежуючих накопичення в них вірусу. Стимуляція фукоіданом утворення ХВК-специфрічних ламінарних структур, здатних зв'язувати вірусні частки, мабуть, є іншим індукованим фукоіданом антивірусним механізмом клітин, який стримує репродукцію, а також внутрішній та міжклітинний транспорт ХВK (Lapshina et al., 2009).

При застосуванні хітозану (1 мг/мл) в уражених клітинах тютюну спостерігали специфічні для ВТМ гранулярні включення, наявність яких пов'язано з початковою стадією репродукції вірусу, тоді як клітини контролю (уражені рослини тютюну без обробки хітозаном) містили здебільшого трубчасті включення, які утворюються з гранулярних у пізні стадії розвитку інфрекції. В оброблених фосфрорно-вольфрамовою кислотою нативних препаратах соку уражених листків поряд з нормальними спостерігали аномальні (набряклі і тонкі) частки ВТМ. Автори вважають, що аномальні віріони, напевно, утворюються у результаті активації внутрішньоклітинних літичних процесів. При обробці хітозаном літична активність у заражених клітин була найбільш вираженою, а кількість аномальних вірусних часток збільшувалась порівняно з контролем. Тобто, обумовлена хітозаном стимуляція літичних процесів, яка викликає деструкцію часток ВТМ, може бути одним із захисних механізмів, перешкоджаючих накопиченню вірусу в клітинах тютюну (Nagorskaja et al., 2011).

О. Г. Коваленко із співавторами (Kovalenko et al., 2010) на прикладі трьох штамів базидіального гриба Ganoderma adspersum, виділених у Грузії, Китаї та Ізраїлі, показали здатність вищих грибів продукувати глікани, які $є$ активними інгібіторами фітовірусної інфрекції. Встановлено, що глікан $G$. adspersum активує захисні механізми рослин тютюну та пригнічує розвиток ВТМ-інфекції в тканинах чутливого хазяїна. Тобто він має широкий спектр антивірусної активності, яка реалізується з одного боку, безпосереднім або опосередкованим пригніченням інфрекційності та репродукції вірусу in vivo, а з іншого - індукцією захисних реакцій надчутливих рослин de novo. Здатність пригнічувати репродукцію та інфекційність ВTM на думку авторів може бути зумовлена впливом полісахариду як на процес інфікування чутливих клітин, так і на ранні етапи репродукції вірусу, а саме: на депротеїнізацію вірусної РНК та/або початкові стадії реалізації вірусного генома в клітині хазяїна.

С. М. Українцева вперше продемонструвала антивірусну активність компактину - природного інгібітора біосинтезу стеринів (продуцент - гриб Penicillium citrinum) в системах рослина-хазяїн: тютюн - ВТМ, картопля XВK (Ukrainceva, 2007). У дослідженнях із застосуванням різних концентрацій компактину було встановлено достовірне зниження ступеню розвитку хвороби при ураженні тютюну сорту Xanthi BTM. При натиранні листків 0,05 \%-водним розчином натрієвої солі компактину (Na-Com) кількість некрозів знижувалась більш ніж у 2 рази, а 0,3 \% розчин практично повністю інгібував розвиток вірусу. В окремих випадках на листках, оброблених компактином, розмір некрозів був меншим, тобто рослини швидше локалізували інфрекцію. Компактин проявляв дію і на стійкість картоплі до X-вірусу за штучного ураження рослин. При натиранні $0,1 \%$ розчином $\mathrm{Na}$-Com листків картоплі на початковому етапі ХВК практично не був виявлений, в подальшому його розповсюдження проходило значно повільніше, ніж у контролі. Захисні властивості компактину проявились і при замочуванні бульб картоплі у 0,3 \% розчині $\mathrm{Na}$-Com. На думку автора, дослідження впливу компактину на фітопатогени можуть слугувати основою для розробки нових засобів захисту рослин від збудників хвороб, у тому числі вірусів (Ukrainceva et al., 2008).

Співробітники Інституту захисту рослин Білорусі вперше для зниження шкідливості вірусних хвороб томату та огірка застосували препарати на основі біологічно активних речовин (Тубелак, який містить вільні амінокислоти, вуглеводи, вітаміни, макро- і мікроелементи; Туберит - препарат, отриманий із побічних продуктів переробки картоплі, і який містить інгібітори трипсину, хімотрипсину та субтилізину (мікробна протеаза), а також інгібітори цистеїнових, аспартильних й металопротеіназ; Препарат С, отриманий з насіння сої, який містить інгібітори Кунітца і Баумана-Бірк; препарат Епін створений в Інституті біоорганічної хімії НАН Білорусі на основі фітогормону природної структури 24-епібрасиноліду). Позитивний вплив препаратів відмічали за передпосівного замочування насіння з наступним поливом та обприскуванням рослин. Більш високий інгібуючий ефект по відношенню до вірусу аспермії томату (ВАТ) та вірусу зеленої крапчастої мозаїки огірка (ВЗКМО) отримано при використанні препаратів Тубелак і Епін. За результатами імуноферментного аналізу препарати сприяли зниженню концентрації ВАТ у рослинах томату у 1,7-2,0 рази, ВЗКМО в рослинах огірка - у 1,5 рази порівняно до контролю. В умовах виробничого досліду біологічна ефективність препарату Епін і препарату Тубелак, на рослини томату в період плодоношення становила 43,4 і 55,2 \%, на рослинах огірка - 65,0 і $60,1 \%$ відповідно, що забезпечило формування додаткового 
урожаю томату до 6,5 \%, огірка - 32,2 \% (Vabishhevich., 2012; Blockaja et al., 2011).

А. В. Дащенко у своїх дослідженнях показала, що використання 0,1\% розчинів гуматів (оксидату торфу і гідрогумату) шляхом передпосівного замочування насіння та дворазового обприскування рослин ехінацеї сорту Принцеса сприяло зниженню ураженості їх вірусом огіркової мозаїки на 15,0 \% та вірусом плямистого в'янення томатів - на 17,0 \% відповідно. При цьому врожайність культури збільшувалась на 27,0-30,0 \%, порівняно з контролем (уражені рослини ехінацеї без обробки гуматами). Автор зазначає, що використані гумати містять високу концентрацію фенольних сполук - компонентів вторинного метаболізму рослин, які можуть виступати в ролі активних фракторів у фрормуванні неспецифічної стійкості рослин ехінацеї до вірусної інфекції (Dashhenko, 2015).

В Інституті мікробіології і вірусології ім. Д. К. Заболотного НАН України, встановлено активність щодо вірусу тютюнової мозаїки препарату Гаупсину, створеного на основі двох штамів Pseudomonas chlororaphis subsp. aureofaciens (Pat. 73682 Ukrai'na). Дослідження свідчать, що біопрепарат Гаупсин з інсектофунгіцидними властивостями також здатен знижувати на 73-100 \% розвиток BTM у рослинах дурману (Datura stramonium L.) та тютюну (Nicotiana tabacum L.). Високу антивірусну активність проявили як самі штами P. chlororaphis subsp. aureofaciens УКМ В-111 і УКМ В-306 - діючі агенти препарату, так і термостабільні водорозчинні фракції, отримані з їх культуральної рідини шляхом осадження етанолом. Останні гальмували на 86-96 \% розвиток інфекції, викликаної ВТМ, проте не були здатні підсилювати рослинний імунітет (Balko et al., 2010).

Г. М. Орловська для пригнічення розвитку вірусної інфекції в рослинах соняшнику застосувала передпосівну обробку насіння біологічними препаратами-стимуляторами росту «БОА» $\mathrm{i}$ «Біофрунге-1» (Orlovs'ka \& Bojko, 2008; . Orlovs'ka, 2013).

За результатами ІФА, обробка препаратом «БОА» в концентрації 0,1\% протягом 60 хв. насіння соняшнику призводила до зниження показників оптичної густини порівняно з необробленим контролем у 2,1 рази. Обробка 0,1 \% препаратом «Біофуннге-1» насіння соняшнику протягом 90 хв. також призводило до зменшення вмісту вірусних антигенів у проростках соняшнику в 3 рази, порівняно з контролем, що сприяло кращому росту і розвитку рослин у подальшому.

Співробітниками лабораторії вірусології Інституту сільськогосподарської мікробіології та агропромислового виробництва НААН України встановлено позитивний вплив біопрепаратів Біогран та Бактопасльон на ріст, розвиток та продукційний процес пробіркових рослин картоплі, вирощених в умовах in vivo за ураження МВК. Передсадивна інокуляція біопрепаратами рослин карто- плі з культури in vitro сприяла збільшенню маси одного клону вірусінфрікованих рослин картоплі на 49,6-45,4 \%. Поряд із збільшенням продуктивності картоплі інокуляція мікробними препаратами сприяла покращенню якісних показників продукції культури, зокрема підвищенню вмісту крохмалю в бульбах на 2,1-6,5 \%, аскорбінової кислоти - на 10,7-19,2 \%. Результати імуноферментного аналізу демонструють зниження концентрації МВК у рослинах картоплі за дії біопрепаратів у 1,4-1,7 раза, що може свідчити про підвищення їх вірусостійкості.

Аналізуючи вищезазначені результати досліджень багатьох вчених, можна стверджувати, що застосування речовин біологічного походження, а також біопрепаратів при вирощувані сільськогосподарських культур є есрективним, екологічно безпечним прийомом зниження шкодочинності вірусних хвороб. Однак існують дані, які свідчать про зворотню дію біологічно активних речовин та мікробних препаратів на розвиток вірусної інфеекції. Так, М. Е. Ладигіна у своїх роботах наводить дані щодо індукції репродукування X-вірусу картоплі за використання гіберелової кислоти (Ladygina \& Babosha, 1996). Е. А. Зоріна зі співавторами (Zorina et al., 2016) дослідили вплив біопрепарату Гамаір (біоагент препарату - штам Bacillus subtilis M-22) на розвиток інфрекції викликаної вірусом мозаїки томату (ВМТо). Встановлено, що при зараженні рослин томатів ВМТо обробка препаратом Гамаір суттєво (у 2 рази по відношенню до контролю) стимулює розвиток вірусного патогену. Тому, беручи до уваги той факт, що біологічно активні речовини та біопрепарати у якості індукторов стійкості діють на фітопатогенні віруси опосередковано, через метаболізм рослини-господаря, необхідно ретельно вивчати їх вплив, як на саму рослину, так і на збудники вірусних хвороб.

Отже, літературні дані свідчать про активний пошук багатьма дослідниками ефективних, екологічно безпечних прийомів зниження шкодочинності вірусних хвороб сільськогосподарських культур, зокрема картоплі. Це питання і досі залишається актуальним та невирішеним у зв'язку з відсутністю надійних засобів захисту рослин від вірусної інфекції.

Висновки. Картопля як культура, що розмножується вегетативно, значною мірою потерпає від перезараження багаточисельними вірусними захворюваннями, і як результат - значні втрати урожаю та якості бульб.

Літературні дані свідчать про активний пошук багатьма дослідниками ефективних, екологічно безпечних прийомів зниження шкодочинності вірусних хвороб сільськогосподарських культур, зокрема картоплі. Фізіологічно активні речовини, антивірусні продукти метаболізму різних мікроорганізмів (грибів, бактерій), водоростей та інгібіторів вірусів із широким спектром антивірусної дії здатні стимулювати природні захисні механізми рослин і $є$ перспективними у стратегії захисту рослин від вірусних інфекцій.

\section{Бібліографічні посилання:}

1. Ambrosov, A. L., Vlasov, Ju. I., Poljakova, T. E., \& Jakusheva, A. S. (1985). Virusnye bolezni ljupina i mery bor'by s nimi [Lupine viral diseases and measures to control them]. Uradzhaj, Minsk, 78 (in Russsian).

2. Balko, O. I., Kiprianova, O. A., \& Kovalenko O. G. (2010). Antyvirusna aktyvnist' biopreparatu Gaupsyn [Antiviral activity of the biological product Gaupsin]. Mikrobiologija i biotehnologija, 2, 51-58 (in Ukrainian). 
3. Barabanova, A. O., Ermak, I. M., \& Reunov, A. V. (2006). Karraginany - sul'fatirovannye polisaharidy krasnyh vodoroslej kak ingibitory virusa tabachnoj mozaiki [Carrageenans - sulfated polysaccharides of red algae as inhibitors of the tobacco mosaic virus]. Rast. resursy, 42(4), 80-86 (in Russian).

4. Blockaja, Zh. V., Vabishhevich, V. V. \& Domash, V. I. (2011). Vozmozhnost' ispol'zovanija biologicheski aktivnyh veshhestv protiv virusov aspermii tomata i zelenoj krapchatoj mozaïki ogurca [Possibility of using biologically active substances against tomato aspermia viruses and cucumber green speckled mosaic]. Zashhita rastenij. Sb. nauch. tr. RUP "Institut zashhity rastenij". Nesvizh, 35, 67-73 (in Russian).

5. Bawden, F. C. (1954). Inhibitors and plant viruses. Adv. vir. res., 2, 31-57.

6. Bobyr', A. D. (1966). Antivirusnye svojstva razlichnyh kul'tur drozhzhej [Antiviral properties of various yeast cultures]. Virusnye bolezni sel'skohozjajstvennyh kul'tur, Kiev, 97-103 (in Russsian).

7. Bobyr', A. D. (1974). Faktory vlijajushhie na obratimost' inaktivacii fitopatogennyh virusov razlichnymi ingibitorami [Factors affecting the reversibility of inactivation of phytopathogenic viruses by various inhibitors]. Materialy IV Vsesojuznogo soveshhanija po virusnym boleznjam rastenij. Naukova dumka, Kiev, 62-67 (in Russsian).

8. Bova T. O., Dmytruk, Ju. O., \& Dmytruk, O. O. (2013). Fitovirusologichnyj monitoryng agrocenoziv z kartopleju Chernigivs'koi' oblasti [Phytovirological monitoring of agrocenoses with potatoes of Chernihiv region]. Misto, Bojanы, 36-41. (in Ukrainian).

9. Brunt, A. A. (2001). Potato virus M (PVM; Genus Carlavirus). Virus and virus-like diseases of potatoes and production of seed potatoes. Kluwer, Dordrecht, 101-108.

10. Chirkov, S. N. (2002). Protivovirusnaja aktivnost' hitozana [Antiviral activity of chitosan]. Prikl. biohim. i mikrobiol., 38(1), 5-13 (in Russsian).

11. Dashhenko, A. V. (2015). Virusni hvoroby likars'kyh roslyn skladnocvitnyh i gubocvitnyh ta zahody z obmezhennja i'h shkidlyvosti v Lisostepu Ukrai'ny [Viral diseases of medicinal plants of Compositae family and Labiatae and measures to limit their harmfulness in the Forest-Steppe of Ukraine]. Dys. kand. s.-g. nauk : 06.01 .11 - fitopatologija, H., 195 (in Ukrainian).

12. Gnutova, R. V., \& Zolotarev, E. V. (2011). Bolezni ovoshhnyh kul'tur i kartofelja na Dal'nem Vostoke Rossii [Diseases of vegetables and potatoes in the Russian Far East]. Dal'nauka, Vladivostok,169 (in Russsian).

13. Gray, R. A. (1955). Activity of an antiviral agent from Nocardia on two viruses in intakt plants. Phytopathology, 45(5), 281-285.

14. Harina, A. V., Skrypov, V. G., \& Budzanivs'ka, I G. (2007). Vplyv rizobakterij na rozvytok infekcii', vyklykanoi' virusom zelenoi' krapchastoi' mozai'ky ogirka na roslynah Cucumis salivus [Influence of rhizobacteria on the development of infection caused by green speckled cucumber mosaic virus of Cucumis salivus]. S.-g. mikrobiologija: mizhvid. temat. nauk. zb. CNTEl, Chernigiv, 5, 179-186 (in Ukrainian).

15. Kandan, A., Ramiah, M., Vasanthi, V. J. Radjacommare, R., Nandakumar, R., \& Ramanazan, A. (2005). Use of Pseudomonas fluorescens-based formulations for management of tomato spotted wilt virus (TSWV) and enhanced yield in tomato. Biocontrol science and technology, 15(6), 553-569.

16. Kolomiec, L. P. (2005). Virusnye bolezni kartofelja na Poles'e Ukrainy [Viral diseases of potatoes in Polesie, Ukraine]. Agromarket, 12, 2-5 (in Russsian).

17. Kolomijec', L. P. (2007). Virusni hvoroby kartopli [Viral diseases of potatoes]. Chernigivshhyna agrarna, № 2(6), 7-9 (in Ukrainian).

18. Kostiw, M. (2011). The occurrence of major potato viruses in Poland. Journal of Plant Protection Research, 51(3), 204-209.

19. Kovalenko O. G., Polishhuk, O. M. \& Vasser, S. P. (2010). Glikany vyshhogo bazydial'nogo gryba Ganoderma adspersum (Schulzer) Donk: otrymannja ta antyvirusna aktyvnist' [Glycans of the higher basidiomycete fungus Ganoderma adspersum (Schulzer) Donk: production and antiviral activity]. Biotehnologija, 3(5), 83-91 (in Ukrainian).

20. Krylov, A. V. \& Usol'ceva, L. V. (1976). Ob ingibirujushhem dejstvii fenol'nyh soedinenij i ih rol' v immunitete rastenij $\mathrm{k}$ virusam [On the inhibitory effect of phenolic compounds and their role in plant immunity to viruses]. Metabolizm bol'nogo rastenija: trudy Biologo-pochvennogo instituta, DVNC AN SSSR, 40(143). 5-19 (in Russsian).

21. Kuz'mich, A., \& Balashova, G. (2011). Vyrozhdenie kartofelja i kak ego izbezhat' [Degeneration of potatoes and how to avoid it]. Ovoshhevodstvo, 4, 52-54 (in Russsian).

22. Ladygina, M. E. \& Babosha, A. V. (1996). Fiziologo-biohimicheskaja priroda virusnogo patogeneza, ustojchivosti i reguljacija antiinfekcionnoj aktivnosti [Physiological and biochemical nature of viral pathogenesis, resistance and regulation of anti-infections activity]. Fiziologija rastenij, 43(5), 729-742 (in Russian).

23. Lapshina, L. A, Reunov, A. V. \& Nagorskaja V. P. (2006). Ingibirujushhee dejstvie fukoidana iz buroj vodorosli Fucus evanescens na razvitie infekcii, vyzvannoj virusom tabachnoj mozaiki v list'jah dvuh sortov tabaka [Inhibiting effect of fucoidan from the brown alga Fucus evanescens on the development of infection caused by the tobacco mosaic virus in the leaves of two varieties of tobacco]. Fiziol. rast., 53(2), 274-279.

24. Lapshina, L. A, Reunov, A. V., Nagorskaja V. P., Zvjaginceva N.M., \& Shevchenko N.M. (2009). Vlijanie fukoidana na ul'trastrukturu kletok mezofilla list'ev Datura stramonium L. i nakoplenie v nih $\mathrm{H}$-virusa kartofelja [Influence of fucoidan on the ultrastructure of mesophyll cells in Datura stramonium leaves and accumulation of potato X-virus in them]. Citologija, 51(6), 484-489 (in Russian).

25. Loon, L. C., Bakker, P. A., \& Pieterse, C. M. (1998). Systemic resistance induced by rhizosphere bacteria. Annu. Rev. Phytopathol., 36, 453-483.

26. Maurhofer, M. Reimmann, C. Schmidli-Sacherer, P. Heeb, S., Haas, D., \& Defago, G. (1998). Salicylic acid biosynthetic genes expressed in Pseudomonas fluorescens strain P3 improve the induction of systemic resistance in tobacco against tobacco necrosis virus. Phytopathol., 88, 678-684. 
27. Metody kontrolju fitovirusologichnogo stanu agrocenoziv z kartopleju ta zernobobovymy kul'turamy. Naukovometodychni rekomendacii' [Methods of control of phytovirological condition of agrocenoses with potatoes and legumes. Scientific and methodical recommendations]. (2015). (Author's team: T. O. Bova, S. V. Derev'janko, O. O. Dmytruk, O. V. Pyrig, Ju. O. Dmytruk, O. O. Kucherjavenko. Chernigiv, 25 (in Ukrainian).

28. Mjet'juz, R. (1973). Inaktivacija virusov [Virus inactivation]. Virusy rastenij. Mir, Moskva, 313-358 (in Russsian).

29. Monitoring virusnyh boleznej kartofelja na Poles'e Ukrainy [Monitoring of viral diseases of potatoes in Polesie, Ukraine]. (2006). (Author's team: Kolomiec L. P., Lebed' L. N., Shevchenko E. P., Dmitruk O. A., Mamchur A. E, Zarickij N. M.). Zashhita rastenij. Sb. nauchn. tr. RUP "Institut zashhity rastenij" NAN Belarusi (Strategija i taktika zashhity rastenij: tez. dokl. mezhdunar. nauch. konf. 28 fevralja - 2 marta 2006 g., Minsk). - Minsk, 30(1), $249-251$ (in Russsian).

30. Musorok, T. I., Rejfman, V. G., \& Zhuravlev, Ju. N. (1976). Vlijanie kinetina na aktivnost' RNKazy i reprodukciju VTM $\checkmark$ list'jah tabaka [Effect of kinetin on RNase activity and TMV reproduction in tobacco leaves]. Metabolizm bol'nogo rastenija. Vladivostok, 120-126 (in Russsian).

31. Nagorskaja, V. P., Reunov, A. V. Lapshina, L. A., Davydova, V. N., \& Ermak, I. M. (2011). Jelektronno-mikroskopicheskoe izuchenie vlijanija hitozana na vnutrikletochnoe nakoplenie i sostojanie chastic virusa tabachnoj mozaiki v list'jah tabaka [Electron microscopic study of the effect of chitosan on the intracellular accumulation and state of tobacco mosaic virus particles in tobacco leaves]. Citologija, 53(2), 185-191 (in Russian).

32. Orlovs'ka, G. M. \& Bojko, A. L. (2008). Vplyv preparativ «BOA» ta «GZ» na nasinnja sonjashnyku (Helianthus annuus L.), urazhenogo virusom pljamystogo ziv'janennja tomativ [Influence of BOA and GZ preparations on sunflower seeds (Helianthus annuus L.) affected by tomato spotting virus]. Agroekologichnyj zhurnal, 2, 193-195 (in Ukrainian).

33. Orlovs'ka, G. M. (2013). Monitoryng, biologichni vlastyvosti virusiv ta profilaktyka virusnyh infekcij sonjashnyku [Monitoring, biological properties of viruses and prevention of viral infections of sunflower]. Avtoref. dys. kand. biol. nauk : 03.00.06 - virusologija. Kyi'v, 22 (in Ukrainian).

34. Pat. 2072779 Rossija, MPK A01N37/06. Induktor ustojchivosti paslenovyh k vozbuditeljam virusnyh boleznej [Inductor of resistance of nightshade to pathogens of viral diseases]. Author's team: Trofimec L. N., Ozercovskaja O. L., Giljazetdinov Sh. Ja., Balahoncev E. N., Janishevskij L. V., Mardashin I. S.; zajavitel' i patentoobladatel' Otdel biohimii i citohimii UNC RAN. - № 93019503/04; zajavl. 14.04.1993 ; opubl. 10.02.1997 (in Russsian).

35. Pat. 73682 Ukrai'na, MPKAO 1N 63/00, S 12 N 1/20. Insektofungicydnyj preparat Gaupsyn dlja borot'by iz shkidnykamy i hvorobamy sil's'kogospodars'kyh kul'tur [Insecticidal drug Gaupsin for pest and disease control of agricultural crops]. Author team: Kiprianova O. A., Goral' S. V.; zajavnyk i patentovlasnyk Instytut mikrobiologii' i virusologii' im. akademika Zabolotnogo NANU. - № 2004031748; zajavl. 10.03.2004 ; opubl. 15.08.2005, Bjul. № 8 (in Ukrainian).

36. Ponomarenko, S. P. \& lutyns'ka, G. O. (1999). Reguljatory rostu. Ekologichni aspekty zastosuvannja [Growth regulators. Environmental aspects of application]. Zahyst roslyn, 12, 15-18 (in Ukrainian).

37. Pridannikov, M. V. (2007). Induktory vyluplenija lichinok cistoobrazujushhih nematod sem. Heteroderidea (Skarbiloich) i perspektiva ih ispol'zovanija dlja zashhity rastenij [Inducers of hatching of larvae of cyst nematodes of family Heteroderidea (Skarbiloich) and the prospect of their use for plant protection]. Avtoref. dis. ... kand. biol. nauk : 06.01.11 - zashhita rastenij, 03.00.19 - parazitologija. Bol'shie Vjazemy, 24 (in Russsian).

38. Reunov, A. V., Lapshina, L. A., Nagorskaja, V. P., \& Eljakova, L. A. (2000). Podavlenie 1.3; 1.6- $\beta$-D-gljukanom infekcij, vyzvannyh H-virusom kartofelja, v list'jah gomfreny i durmana [Suppression 1.3; 1.6- $\beta$-D-glucan of Potato Virus X-Virus Infections in Gomphrene and Datura leaves]. Fiziol.rast., 47(2), 240-243 (in Russsian).

39. Rouhier, P., Kopp, M., Begot, V., Bruneteau, M., \& Fritig, B. (1995). Structural feautures of fungal $\beta$-D-glucans for the efficient inhibition of the initiation of virus infection on Nicotiana tabacum. Phytochemistry, 39, 57-62.

40. Ryu, C. M., Murphy, J. F., Mysore, K. S., \& Kloepper, J. W. (2004). Plant growth-promoting rhizobacteria systemically protect Arabidopsis thaliana against Cucumber mosaic virus by a salicylic acid and NPR1-independent and jasmonic aciddependent signaling pathway. Plant J., 39(3), 381-392.

41. Shelud'ko, Ju. M. (1970). Fitovirusologija [Phytovirusology]. Vyshha shkola, Kyi'v, 272 (in Ukrainian).

42. Shevchuk, V. K. \& Doroshenko, O. L. (2000). Biostymuljatory - proty hvorob [Biostimulants - against diseases]. Zahyst roslyn, 9, 7 (in Ukrainian).

43. Sheveluha, V. S. \& Blinovskij, I. K. (1990). Sostojanie i perspektivy issledovanij i primenenija fitoreguljatorov v rastenievodstve. Reguljatory rosta rastenij [Status and prospects of research and application of phytoregulators in crop production. Plant growth regulators]. Agrompromizdat, Moskva, 6-35 (in Russsian).

44. Slovakova, L., Liskova, D., \& Capek, P. (2000). Defence responses against TNV infaktion induced by galactoglucomannan-derived oligosaccharides in cucumber cells. Eur. J. Plant Phatol., 106, 543-553.

45. Soroka, S. V. (2005). Integrirovannye sistemy zashhity sel'skohozjajstvennyh kul'tur ot vreditelej, boleznej i sornjakov [Integrated systems for protecting crops from pests, diseases and weeds]. Belorusskaja nauka, Minsk, 119-120 (in Russsian).

46. Stubler, D. \& Buchenauer, H. (1996). Antiviral activity of the glucan ichenan (Poly- $\beta\{1 \rightarrow 3,1 \rightarrow 4\}$ D-anhydroglucose). J. Phytopatol.,144, 37-43.

47. Suchasnij stan agrocenozu kartopljanogo polja i shljahi reguljuvannja jogo chisel'nosti [The current state of the agrocenosis of the potato field and ways to regulate its number]. [Electronic resources]. Access mode: http://potatoclub.com. ua/index.php (in Ukrainian).

48. Taran, N. Ju., Svjetlova, N. B., \& Okanenko, O. A. (2004). Reguljatory rostu u formuvanni adaptyvnyh reakcij roslyn do posuhy [Growth regulators in the formation of adaptive reactions of plants to drought]. Visnyk agrarnoi' nauky, 8, 29-32 (in Ukrainian).

49. Tesljuk, P. S., Kupryjanov, V. P., Pahol'chuk, V. D., Pashkovs'ka, Ju. V., Tesljuk, L. P., Kyjenko, Z. B., \& Pahol'chuk, I. V. (2008). Poradnyk kartopljara [Poptato Guide]. Urozhaj, Kyev, 231 (in Ukrainian). 
50. Ukrainceva, S. N. (2007). Izuchenie vozmozhnosti ispol'zovanija kompaktina v kachestve biopesticida protiv fitopatogenov i poluchenie vysokoproduktivnyh shtammov griba Penicillium citrinum - producenta kompaktina [Studt of the possibility of using compactin as a biopesticide against phytopathogens and obtaining highly productive strains of the fungus Penicillium citrinum - a producer of compactin]. Avtoref. dis. kand. biol. nauk: 06.01.11 - zashhita rastenij, 03.00 .23 biotehnologija. Bol'shie Vjaz'my, 26 (in Russian).

51. Ukrainceva, S. N., Pridannikov, M. V., \& Dzhahvija, V. G. (2008). Kompaktin - potencial'nyj biopesticid [Compactin is a potential biopesticide]. Zashhita i karantin rastenij, 2, 64 (in Russian).

52. Vabishhevich, V. V. (2012). Virusnye bolezni tomata i ogurca zashhishhennogo grunta i puti ogranichenija ih vredonosnosti [Viral diseases of tomato and cucumber in greenhouses and ways to limit their harmfulness]. Avtoref. dis. ... kand. biol. nauk : 06.01 .07 / V. V. Vabishhevich. Priluki Minskogo rajona, 22 (in Russian).

53. Vlasov, Ju. I. \& Larina, Je. I. (1982). Sel'skohozjajstvennaja virusologija [Agricultural Virology]. Kolos, Moskva, 239 (in Russsian).

54. Zherebchuk, L. K., Olevins'ka, Z. M., \& Romas', I. J. (1974). Vlijanie gibberellina na soderzhanie nukleinovyh kislot $\checkmark$ list'jah zdorovyh i porazhennyh $\mathrm{H}$-virusom rastenij kartofelja [The effect of gibberellin on the content of nucleic acids in the leaves of healthy and X-virus infected potato plants]. Materialy IV Vsesojuznogo soveshhanija po virusnym boleznjam rastenij. Naukova dumka, Kiev,159-164 (in Russsian).

55. Zorina, E. A., Fominyh, T. S., \& Novikova, I. I. (2016). Vlijanie shtamma Vacillus subtilis M-22 - producenta biopreparata Gamair na razvitie infekcii virusa mozaiki tomata [Influence of Bacillus subtilis strain M-22-producer of biological product Gamair on the development of tomato mosaic virus infection]. Vestnik zashhity rastenij, 2(88), 50-55 (in Russian).

Kucheriavenko O. O., Scientific Researcher, Institute of Agricultural Microbiology and Agro-Industrial Production of NAAS of Ukraine, Chernihiv, Ukraine

Pyrih O. V., PhD (Agricultural Sciences), Research Agronomist, STOV «Druzhba Nova», Varva, Chernihiv region, Ukraine

Tymoshenko O. P., PhD (Agricultural Sciences), Associate Professor, National University "Chernihiv polytechnics», Chernihiv, Ukraine

Dmytruk 0. O., Scientific Researcher, Institute of Agricultural Microbiology and Agro-Industrial Production of NAAS of Ukraine, Chernihiv, Ukraine

Bondar I. M., Senior Lecturer, National University «Chernihiv polytechnics», Chernihiv, Ukraine

Ways to reduce the harmfulness of pathogens of viral potato diseases

The research results of long-term data monitoring of the prevalence of viral diseases in nurseries of elite potato seedlings have been presented. A result of its - the loss of the harvest and tuber qulity. It has been established that the most common are M-, S-, Y-potato viruses, both in monoinfection and in pathogen complexes. Classical methods such as biotechnological, phytosanitary, chemical and agrotechnical to control viral potato diseases have been described. An analysis of research on the use of physiologically active substances, antiviral metabolic products of various microorganisms and inhibitors of viruses with a wide range of antiviral activity has been conducted. It has been found out that they are generally able to stimulate the natural defense mechanisms of plants and are promising in the strategy of protecting plants from viral infections.

Key words: potato, viral infection, biological antiviral substances, physiologically active substances, biological preparations. 